\title{
Використання високочастотної вентиляції при гострому респіраторному дистрес-синдромі у дітей першого року життя після кардіохірургічних операцій
}

\author{
Петренко А. П., Бойко С. М., Мошківська Л. В., Хеміо Арнес С. Г., \\ Лазоришинець В.В.
}

ДУ «Національний інститут серцево-судинної хірургії імені М. М. Амосова НАМН» (Київ)

\begin{abstract}
Основними завданнями штучної вентиляції легень (ШВЛ) при гострому респіраторному дистрес-синдромі (ГРДС) є усунення гіперкапнії, покращення оксигенації та уникнення вентилятор-індукованого ушкодження легень. Метою роботи було оцінити ефективність використання високочастотної вентиляції при ГРДС у 15 дітей, прооперованих із приводу вроджених вад серця в умовах штучного кровообігу.

Матеріали та методи. Із серпня 2014 року по березень 2018 року в ДУ «НІССХ імені М. М. Амосова НАМН» було прооперовано 15 дітей віком від 5 днів до 6 міс., вагою від 3 кг до 6 кг із дефектом міжшлуночкової перегородки (ДМШП) з легеневою гіпертензією (ЛГ), атріовентрикулярною комунікацією (АВК) з ЛГ, транспозицією магістральних судин (ТМС).

Результати. У всіх дітей уже через 3 години після початку проведення високочастотної осциляторної вентиляції (ВЧОВ) відмічалися покращення в газовому складі артеріальної крові. На традиційній ШВЛ із «жорсткими» параметрами до початку ВЧОВ відмічалися такі показники газового складу артеріальної крові: $\mathrm{pH}$ 7,1; pCO2 80 mmHg; BE - 15; $\mathrm{PaO} 250 \mathrm{mmHg}$; $\mathrm{SaO} 2$ 60\%. Через 3 години на ВЧОВ: pH 7,4; pCO2 $35 \mathrm{mmHg}$; $\mathrm{BE}-3 ; \mathrm{PaO} 270 \mathrm{mmHg} ; \mathrm{SaO} 290 \%$.

Висновки. Проведення на ранніх стадіях ГРДС вентиляції методом ВЧОВ у дітей першого року життя кардіохірургічного профілю супроводжувалося покращенням газообміну артеріальної крові, про що свідчить редукція індексу оксигенації і ознак вентилятор-індукованого ушкодження легень.
\end{abstract}

Ключові слова: високочастотна вентиляція, гострий респіраторний дистрес-синдром, вроджені вади серия.

Розвиток тяжких ускладнень після кардіохірургічних операцій у дітей першого року життя зумовлений складними вродженими вадами серця (ВВС), початковою важкістю стану, генетичною патологією, зниженням механізмів місцевого та загального імунітету [1].

Всі діти раннього віку, які перенесли операцію зі штучним кровообігом (ШК), входять до групи ризику розвитку різноманітних післяопераційних ускладнень. Основними причинами розвитку легеневих ушкоджень у дітей є: довготривалий наркоз, екстракорпоральний кровообіг, особливості проведення штучної вентиляції легень (ШВЛ) під час кардіохірургічної операції, початково скомпрометовані легені та потреба в проведенні ШВЛ із «жорсткими» параметрами в післяопераційному періоді. ШВЛ із «жорсткими» параметрами в умовах уже наявного ушкодження легень може спричинити та/ або посилити подальше ушкодження легеневої паренхіми. Це сприяє розвитку таких ускладнень, як вентилятор-індуковане ушкодження легень, руйнування екзогенного сурфактанту, прогресування синдрому системної запальної відповіді, септичного стану та синдрому поліорганної недостатності [3].
У зв'язку з гіперкапнією та недостатньою оксигенацією використання традиційної ШВЛ у цих пацієнтів неефективне, тому альтернативою стала високочастотна осциляторна вентиляція (ВЧОВ) [2].

Мета - оцінити ефективність використання високочастотної вентиляції на ранніх стадіях гострого респіраторного дистрес-синдрому в дітей першого року життя, прооперованих із приводу вроджених вад серця в умовах штучного кровообігу.

Матеріали та методи. Із серпня 2014 року по березень 2018 року в ДУ «НІССХ імені М. М. Амосова НАМН» було прооперовано 15 дітей віком від 5 днів до

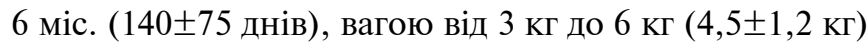
3 дефектом міжшлуночкової перегородки (ДМШП) 3 легеневою гіпертензією (ЛГ), атріовентрикулярною комунікацією (АВК) з ЛГ, транспозицією магістральних судин (ТМС) (табл. 1).

Зменшення індексу оксигенації у відповідь на «жорсткі» параметри вентиляції свідчило про те, що традиційна ШВЛ малоефективна і потенційно небезпечна для розвитку вентилятор-індукованого ушкодження легень, що було показанням до початку проведення ВЧОВ. Потенційно небезпечною для розвитку вен- 


\section{Таблиця 1}

Розподіл пацієнтів за типом $B B C$

\begin{tabular}{lc} 
ВВС & Кількість (\%) \\
\hline ДМШП з ЛГ & $5(34 \%)$ \\
\hline АВК з ЛГ & $9(60 \%)$ \\
\hline TMC & $1(6 \%)$
\end{tabular}

ДМШП - дефект міжшлуночкової перегородки, ЛГ - легенева гіпертензія, АВК - атріовентрикулярна комунікація, ТМС транспозиція магістральних судин

тилятор-індукованого ушкодження легень вважалася сукупність таких параметрів традиційної вентиляції (pressure SIMV), необхідних для підтримки адекватного газообміну:

- частота вдихів-видихів більше 40 у хв.,

- Pinsp більше 25 см вод. ст. для новонароджених і більше 30 см вод. ст. для малюків віком старше 1 місяця,

- МАР більше 12-14 см вод. ст.,

- потреба в токсичних концентраціях кисню $\left(\mathrm{FiO}_{2}>0,6\right)$ при РЕЕР більше $+8-10$ см вод. ст.,

- величина індексу оксигенації <100 [4].

Високочастотна вентиляція всім хворим проводилася для розправлення ателектазів, збільшення альвеолярної поверхні для газообміну, зменшення внутрішньолегеневого шунтування та покращення співвідношення вентиляція/перфузія. На відміну від традиційної вентиляції, оксигенацію і вентиляцію при використанні ВЧОВ можна коригувати окремо. Для досягнення зазначених вище цілей використовувався апарат ВЧО 3100В SensorMedics, Viasys (США) 3 такими параметрами: МАР встановлювали на 2-3 см вод. ст. вище, ніж МАР при традиційній вентиляції, та підвищували на 1-2 см вод. ст. до покращення оксигенації; амплітуду встановлювали до появи легкої вібрації грудної клітини. Газообмін контролювали кожні 15 хвилин до підбору оптимальних параметрів вентиляції. Кожна зміна параметрів ВЧОВ супроводжувалася оцінкою газів артеріальної крові.

У всіх дітей на початковому етапі проведення ВЧОВ з метою покращення адаптації до вентиляції використовували медикаментозний сон та міорелаксацію, що досягалося інфузією фентанілу в дозі 5 мкг/кг/год. і болюсним введенням піпекуронію броміду 0,1 мг/кг. В гемодинамічній підтримці використовували весь спектр катехоламінів.

Результати та обговорення. В усіх дітей уже через 3 години після початку проведення ВЧОВ відмічалися покращення в газовому складі артеріальної крові. Показники газового складу артеріальної крові, що відмічалися на традиційній ШВЛ із «жорсткими» параметрами до початку ВЧОВ та при ВЧОВ, наведено в табл. 2.

\section{Таблиця 2}

Характеристика показників газового складу артеріальної крові до і в перші 3 години використання $B 4 O B$

\begin{tabular}{|c|c|c|c|}
\hline Показники & Традиційна ШВЛ & ВЧОВ & $\mathbf{p}$ \\
\hline $\mathrm{pH}$ & $\begin{array}{c}7,22 \pm 1,8 \\
\text { (від 7,1 до 7,3) }\end{array}$ & $\begin{array}{c}7,31 \pm 1,5 \\
\text { (від 7,2 до 7,45) }\end{array}$ & $p<0,05$ \\
\hline $\mathrm{pCO}_{2}, \mathrm{mmHg}$ & $\begin{array}{c}66,5 \pm 15,1 \\
\text { (від } 45 \text { до } 80 \text { ) }\end{array}$ & $\begin{array}{c}42,0 \pm 5 \\
\text { (від } 35 \text { до 45) }\end{array}$ & $p<0,05$ \\
\hline $\mathrm{PaO}_{2}, \mathrm{mmHg}$ & $\begin{array}{c}53,3 \pm 8,4 \\
\text { (від } 50 \text { до 60) }\end{array}$ & $\begin{array}{c}76,2 \pm 4,8 \\
\text { (від } 70 \text { до 80) }\end{array}$ & $p=0,07$ \\
\hline BE & $\begin{array}{c}-8,7 \pm(-5,2) \\
\text { (від -5 до -15) }\end{array}$ & $\begin{array}{c}-3,8 \pm(-1,1) \\
\text { (від -3 до -5) }\end{array}$ & $p<0,05$ \\
\hline $\mathrm{SaO}_{2}, \%$ & $\begin{array}{c}70,3 \pm 19,1 \\
\text { (від } 60 \text { до 90) }\end{array}$ & $\begin{array}{c}88,4 \pm 7,8 \\
\text { (від } 80 \text { до 95) }\end{array}$ & $p=0,06$ \\
\hline
\end{tabular}

\section{Таблиця 3}

Характеристика показників системної гемодинаміки до i в перші 3 години використання ВЧОВ

\begin{tabular}{lccc} 
Показники & Традиційна ШВл & ВчОВ & $\mathbf{p}$ \\
\hline АТ систолічний & $\begin{array}{c}51 \pm 6,5 \\
\text { (від 45 до 55) }\end{array}$ & $\begin{array}{c}73,3 \pm 10 \\
(\text { від 65 до 80) }\end{array}$ & $\mathrm{p}=0,12$ \\
\hline \multirow{2}{*}{ АТ діастолічний } & $\begin{array}{c}38,4 \pm 1,3 \\
\text { (від 38 до 40) }\end{array}$ & $\begin{array}{c}50,3 \pm 5,2 \\
\text { (від 45 до 54) }\end{array}$ & $\mathrm{p}=0,09$ \\
\hline \multirow{2}{*}{ АТ середній } & $\begin{array}{c}43,2 \pm 4,1 \\
\text { (від 40 до 45) }\end{array}$ & $\begin{array}{c}56 \pm 4 \\
(\text { від 55 до 60) }\end{array}$ & $\mathrm{p}=0,23$ \\
\hline ЧСС & $\begin{array}{c}178 \pm 20 \\
\text { (від 170 до 185) }\end{array}$ & $\begin{array}{c}137 \pm 6,1 \\
\text { (від 135 до 140) }\end{array}$ & $\mathrm{p}=0,33$ \\
\hline ЦВТ & $\begin{array}{c}12,5 \pm 1,5 \\
\text { (від 11 до 14) }\end{array}$ & $\begin{array}{c}11,8 \pm 0,8 \\
\text { (від 11 до 12) }\end{array}$ & $\mathrm{p}=0,09$
\end{tabular}

АТ - артеріальний тиск, ЧСС - частота серцевих скорочень, ЦВТ - центральний венозний тиск

Також покращувалися параметри системної гемодинаміки, що супроводжувалося зниженням потреби в катехоламінах (табл. 3).

Збільшення величини $\mathrm{PaO}_{2}$ в змішаній венозній крові 29 27 (з 22 до 35) і насичення $\mathrm{SvO} 255 \pm 12$ (з 42 до 65) свідчить про покращення продуктивності серцевосудинної системи у дітей з ГРДС і збільшення доставки кисню до тканин, що відображає збільшення серцевого викиду.

В середньому для нормалізації газообміну знадобилася вентиляція методом ВЧОВ від 24 до 96 годин. Респіраторна підтримка тривала в середньому 15 діб.

У групі із 15 дітей із ГРДС, в лікуванні яких на ранніх стадіях патологічного процесу використовувалася ВЧОВ, було три летальні випадки - на 7-му та 10-ту добу. Причиною смерті став сепсис, септичний шок і внутрішньошлуночковий крововилив на 6-ту добу.

Висновки. Проведення на ранніх стадіях ГРДС вентиляції методом ВЧОВ у дітей першого року життя 
кардіохірургічного профілю супроводжувалося покращенням газообміну артеріальної крові, про що свідчить редукція індексу оксигенації і ознак вентиляторіндукованого ушкодження легень.

Проведення ВЧОВ на ранніх стадіях ГРДС у дітей першого року життя кардіохірургічного профілю супроводжувалося покращенням основних показників системної гемодинаміки. Підтверджувалося зниженням тахікардії, ЦВТ в поєднанні з підвищенням величини АТ систолічного, АТ діастолічного, АТ середнього. На фоні проведення ВЧОВ відмічалося зменшення потреби в катехоламінах. Покращення показників оксигенації змішаної крові $\left(\mathrm{PaO}_{2}, \mathrm{SvO}_{2}\right)$ говорить про збільшення доставки кисню до тканин, що відображає збільшення серцевого викиду. Покращення показників системної гемодинаміки та газового складу артеріальної крові даного методу ВЧОВ є ефективнішим по- рівняно з традиційною ШВЛ на ранніх стадіях ГРДС у дітей кардіохірургічного профілю.

\section{Література}

1. Bernard G.L., Artigas A., Brigham K.L. Report of the American-Europian concensus conference on acute respiratory distress; syndrome definitions, mechanisms, relevant outcomes, and clinical trial coordination - Crit. Care Med. - Ст. 46-52 1994 г.

2. Сатишур О. Е. Механическая вентиляция легких. М. : Мед. лит., 2017. - 352 с.

3. Атаханов, И. Э. Клинико-физиологическое обоснование струйных высокочастотных методов вспомогательной и искусственной вентиляции легких при острой дыхательной недостаточности: Автореферат дис. докт. мед. наук. - Ташкент. 1995 г.

4. Беляев А.В. Острый респираторный дистресс-синдром. / А.В.Беляев - К.: КИМ, 2015. - 215 с.

\title{
Effectiveness of high-frequency ventilation during acute respiratory distress syndrome in children of one year of age after cardiac surgery
}

\author{
Petrenko A., Boyko S., Moshkivska L., Khemio Arnes S., Lazoryshynetz V. \\ National M. M. Amosov Institute of Cardiovascular Surgery National Academy of Medical Sciences of Ukraine (Kyiv)
}

The main objectives of ventilation for ARDS are to eliminate hypercapnia, improve oxygenation and prevent ventilatorinduced lung damage. The aim of the work was to evaluate the effectiveness of using high-frequency ventilation in ARDS in 15 children operated on congenital heart defects in conditions of artificial circulation.

Materials and methods. From August 2014 to March 2018 in the "National M. M. Amosov Institute of Cardiovascular Surgery National Academy of Medical Sciences of Ukraine" 15 children in the age of from 5 days to 6 months (weight from $3 \mathrm{~kg}$ to $6 \mathrm{~kg}$ ) with an ventricular septal defect with pulmonary hypertension $(\mathrm{LH})$, atrioventricular communication with $\mathrm{LH}$, transposition of the great arteries underwent heart bypass surgery.

Results. All children had an improvement in the gas composition of blood in 3 hours after the beginning of the high frequency ventilation. On traditional mechanical ventilation with "hard" parameters before the beginning of high frequency ventilation, such indices of the arterial blood gas composition were noted: $\mathrm{pH} 7.1 ; \mathrm{pCO}_{2} 80 \mathrm{mmHg} ; \mathrm{BE}-15 ; \mathrm{PaO}_{2} 50 \mathrm{mmHg}$; $\mathrm{SaO} 260 \%$, and after 3 hours on the RF: $\mathrm{pH} 7.4 ; \mathrm{pCO}_{2} 35 \mathrm{mmHg}$; BE-3; $\mathrm{PaO}_{2} 70 \mathrm{mmHg} ; \mathrm{SaO}_{2} 90 \%$.

Conclusions. The early stages of ARDS ventilation by the HFV method in children of the first year of life with CHD were accompanied by an improvement in the gas exchange of the arterial blood, as indicated by a reduction in the oxygenation index and signs of ventilator-induced lung damage.

Key words: high-frequency ventilation, acute respiratory distress syndrome, congenital heart defects. 